\title{
ECONOMIC GROWTH AND ECONOMIC INEQUALITY IN VISEGRÁD COUNTRIES: EMPIRICAL ANALYSIS
}

\author{
Nemanja Lojanica* \\ Faculty of Economics, University of Kragujevac, \\ Kragujevac, Republic of Serbia \\ Tijana Tubić Ćurčić \\ Faculty of Economics, University of Kragujevac, \\ Kragujevac, Republic of Serbia
}

\begin{abstract}
Since economic inequality represents a burning issue nowadays, the examination of its connection to the dynamics of economic growth is very important. The application of econometric methodology in modeling dependency of economic growth and economic inequality is becoming more and more widespread. In this paper we examine the impact of economic growth on the movement of economic inequality in Visegrád countries in the period from 2005 to 2015, by applying econometric methodology in the area of regression panel model analysis. The results show that the economic growth does not result in reduction of economic inequality. More precisely, an increase of $1 \%$ in economic growth leads to the growth of GINI coefficient by 0.19\%. In the context of the reduction of economic inequality, policy-makers should pay special attention to socio-democratic factors of inequality, as well as to the tax (redistributive) policy.
\end{abstract}

Keywords: economic growth, economic inequality, GINI coefficient, Visegrad group countries, econometric analysis, panel regression

JEL classification: C33, E24, O4O

*nemanjalojanica@yahoo.com 
36 | ECONOMIC GROWTH AND ECONOMIC INEQUALITY IN VISEGRÁD COUNTRIES: EMPIRICAL ANALYSIS

\section{PRIVREDNI RAST I EKONOMSKA NEJEDNAKOST \\ U ZEMLJAMA VIŠEGRADSKE GRUPE: EMPIRIJSKA ANALIZA}

Sažetak: Budući da ekonomska nejednakost trenutno predstavlja sve izraženiji problem, veoma je značajno ispitivanje njene povezanosti sa dinamikom privrednog rasta. Primena ekonometrijske metodologije u modeliranju zavisnosti između privrednog rasta i ekonomske nejednakosti postaje sve rasprostranjenija. U ovom radu se ispituje uticaj privrednog rasta na kretanje ekonomske nejednakosti $u$ zemljama Višegradske grupe u periodu od 2005. do 2015. godine, primenom ekonometrijske metodologije u oblasti analize regresionih panel modela. Rezultati pokazuju da privredni rast nije generator smanjenja ekonomske nejednakosti. Preciznije, povećanje privrednog rasta za 1\% dovodi do rasta GINI koeficijenta za 0,19\%. U kontekstu smanjenja ekonomske nejednakosti, nosioci ekonomske politike bi trebalo da posebnu pažnju posvete sociodemografskim faktorima nejednakosti, kao i poreskoj (redistributivnoj) politici.

Ključne reči: privredni rast, ekonomska nejednakost, GINI koeficijent, zemlje Višegradske grupe, ekonometrijska analiza, panel regresija

\section{INTRODUCTION}

Wealth distribution is a pressing issue nowadays and is often argued about in the context of long-term development. Economic thinkers gave the question of (in)equality of income distribution a huge significance. Marx considered that the dynamics of accumulation of private capital leads to the growth of power and strong concentration of wealth in the hands of a few. According to Kuznets, the equalization of growth strength, competence and technical progress spontaneously leads to lesser inequality and bigger stabilization in advanced growth stages (Piketty, 2015). During the eighteen and nineteen century, great number of authors, among which Thomas Malthus and David Ricardo stand out, had the apocalyptic ideas regarding social distribution of wealth. According to Malthus (1798) the key problem is overpopulation. His recommends terminating each system of help to the poor and strictly controlling their birth rate, since otherwise the whole world could sink into chaos and poverty. Ricardo (1817) emphasizes that the problem regarding the long-term development is related to the price of land and the height of land rent. His principle of rareness even today has economic justification, but his predictions, as well as Malthus's, in continued growth of agricultural land proved wrong, since he did not predict the significance and the role of technical progress. On the other hand, Marx (1867) starts from Ricardo's 
(1817) principle of rareness and his main conclusion can be called unlimited tendency of capital to accumulate and concentrate in endless ratios, without natural limit. After Marx, Kuznets (1955) develops his theory in which inequality of incomes is automatically reduced in advanced stages of capitalistic development, regardless of the chosen economic policy and country characteristics, while it is stabilized on the acceptable level.

Growing inequality in income distribution within and among countries in 2015 was marked by the experts of World Economic Forum as the first topic that dominates global agenda. As it is stated in the paper by Bandelj and Mahutga (2010) the growth of economic inequality in transitional economies was marked after 1990 when the countries started the process of transition from central and planned to market economy. At the beginning of the transition, economic inequality in these countries was low. However, over time inequalities and differences among them increased. Besides, the convergence towards life standard of developed economies was weak and different among transition economies (EBRD, 2013). Different level of income inequality in transition economies is the consequence of different government approaches of these countries to stabilization, liberalization and privatization (Ivanova, 2007; Bandelj and Mahutga, 2010; Porras, 2010), as well as different social systems and policies (Wang, Caminada and Goudswaard, 2013). However, even though the increase of economic inequalities was happening gradually and over long period of time, the worsening of economic position of lower middle class became obvious with the economic crisis in 2008. This economic crisis had strong impact on Europe, reversing long-term trends of convergence of life standard and significantly burdening social protection system. Economic inequality was increased in most countries members of European Union and caused worry regarding the sustainability of growth and social cohesion. In 2016 Gini coefficient for EU-28 was 30.8. The largest inequalities among the countries members of EU, with Gini coefficient larger than 35 were recorded in Bulgaria and Lithuania, while the smallest inequalities in the distribution of income were recorded in Netherlands, Belgium, Finland, Czech Republic, Slovenia and Slovakia where Gini coefficient was less than 27 (European Commission, 2018).

In accordance with the stated, the research subject is interdependence of economic inequality and economic growth at the example of Visegrad countries (Czech Republic, Hungary, Poland and Slovakia) in the period from 2005 to 2015. The contribution of work is twofold. Firstly, the sample of countries that realize positive growth rates, and are categorized in the economies with rapidly growing market is analyzed in the paper. Secondly, a specific methodological econometric panel as a corresponding methodological framework is used. The aim of this paper is to examine SCHOOL OF BUSINESS, 2/2019, 35-51 
38 | ECONOMIC GROWTH AND ECONOMIC INEQUALITY IN VISEGRÁD COUNTRIES: EMPIRICAL ANALYSIS

through theoretic and empirical analysis whether there is the influence of economic growth on economic inequality in Visegrad countries, and if there is, what it is. Pursuant to the chosen subject and set research objective, we start from the following research question: Does economic growth reduce economic inequality in analyzed economies?

The paper consists of six sections. After the introduction part, theoretical grounds of interdependence of economic inequality and economic growth are presented. The results of relevant empirical research on relation between these two variables are shown in the third section. In the fourth section the methodology of research is explained, while the results of the research are presented in the fifth section of the paper. The sixth section summarizes the conclusions and defines possible directions of further research.

\section{THEORETICAL ASPECT OF INTERDEPENDENCE OF ECONOMIC INEQUALITY AND ECONOMIC GROWTH}

During the period of Keynesian influence, the issue of economic inequality was not paid much attention to since the predominant belief was that the higher economic growth, the smaller the problem of economic development and inequality is. However, with a new wave of globalization the things have significantly changed. (Dewhurst and Mutis-Gaitan, 1995). During the 90s of XX century, the research on economic inequality and income convergence per capita, i.e. whether less developed economies can grow faster in relation to developed economies, becomes a more and more popular direction of research (Berumen and Perez Megino, 2015). Income inequality represents about three quarters of total global inequality (Milanović, 2013). During previous decades, the gap between rich and poor measured by Gini coefficient was increased both in most developing and emerging countries and in developed economies (OECD, 2010; OECD, 2011). The growth of economic inequality is encouraged by globalization, trade and financial integration and accelerated technological progress.

Theoretic basis for the examination of relations between economic inequality and economic growth is represented by Kuznets hypothesis. Kuznets (1995), wishing to answer the question whether during the economic growth inequality of some country is increased or decreased in long-term income distribution, i.e. which factors determine the level and movement of inequality, introduces the concept of "the inverted U curve". According to Kuznets, economic inequality was low in preindustrial societies in which most people lived at subsistence level. With the beginning of industrialization, the gap started to grow due to the growth of earnings of 
Nemanja Lojanica, Tijana Tubić Ćurčić | 39 factory workers in relation to the earnings of agricultural workers, and it kept growing more and more with the increased specialization of industrial workers. After that, inequalities decreased slowly since the country redistributed tax incomes in favor of poorer population. Kuznets' hypothesis was influential during the twentieth century, and inequality in the form of inverted letter $U$ was well supported by the facts. The curve in the form of inverted letter $U$ can be explained in the following way: in early stages of development, that was characterized by the low level of income, the main growth driver was the investment in the infrastructure and physical capital, and inequality encouraged growth by the distribution of resources between those that save more and invest. Besides, with the growth of industry and higher degree of urbanization inequalities increased. In a more advanced growth stage, with the accumulation of wealth and with the transition to human capital and advances in technology inequalities decrease. The last, third stage is characterized by higher level of wealth and main generator of growth becomes human capital. Due to this, inequalities decrease and the growth is still realized.

However, during the last few years this hypothesis is more and more brought into question, i.e. instead of inverted letter $U$ inequality obtains more the form of regular letter $U$, since by the beginning of twentieth century it was high, and then it fell down by the middle of the century and since the 70s, it has grown again (Keeley, 2015). Besides, the opinion that inequality is exclusively determined by the degree of reached level of economic development (Kuznets' hypothesis) has recently been gradually giving way to the attitudes that one of the important determinants of the level and dynamics of economic development is precisely economic inequality. Numerous theoretical and empirical papers published during the 1990s testify that income distribution has significant macroeconomic implications. In accordance with this, two opposite attitudes stand out. The first, according to which inequality is good for growth, i.e. the acceleration of economic growth can be realized exclusively on the basis of the increase of inequality level. The second emphasizes that more equal income distribution has stimulating impact on growth, i.e. that unequal income distribution is harmful to growth.

Empirical research of the relation between economic inequality and economic growth has shown that there are numerous mechanisms of cause and effect relationship. According to traditional approach (Kaldor, 1965) saving as a basic resource of economic growth has a mediator role. Since there is a growing boundary preference to saving, the rich will save more than the poor. Hence, the bigger inequality in income distribution concentrates money in the hands of those who are inclined to save and invest, by which economic growth is being improved. In accordance with the SCHOOL OF BUSINESS, 2/2019, 35-51 
40 | ECONOMIC GROWTH AND ECONOMIC INEQUALITY IN VISEGRÁD COUNTRIES: EMPIRICAL ANALYSIS

said, it is concluded that equal income distribution decreases economic growth, and unequal distribution makes it higher. This approach is based on the so called "old growth theory" according to which the growth is based on faster accumulation of capital.

Contrary to the traditional approach, in newer literature identifies four key mechanisms that connect initial income distribution with economic growth: imperfect loan market, income redistribution between different groups, political (in)stability and social conflicts. Modern approach predicts negative impact of inequality on economic growth that is explained by the fact that in developing countries the poor have numerous limitations when taking a loan, do not have opportunities for investments and extremely poor do not participate in production process, which decreases productive investment and finally results in the decrease of long-term growth rate (Galor and Zeira, 1993). Income redistribution via progressive taxation discourages the most capable in a society to save and decreases the incentives for private investments, which negatively affects growth (Bertola, 1993; Alesina and Rodrick, 1994; Perotti, 1996). The poorer, so called medial voter, the bigger the initial inequality, and the bigger is the insisting on redistribution and taxation. Inequality in income distribution increases political and social instability, which in turn affects the increase of uncertainty and risks of nonperformance of contracting obligations, obeying the law and protection of assets, the decline of expected production factors income, by which the accumulation of capital is being slowed down, thus economic growth as well (Helpman, 2004; Tachibanacki, 2005; Weil, 2005). Alesina and Perroti (1996) also concluded that political instability decreases the incentives for investments, which decreases the rate of economic growth. However, Thorbecke and Charumilind (2002) have shown that regardless of the type of political instability, the relation between economic inequality and political instability is neither linear, nor monotonous, so, on some levels of economic inequality, a further increase of this inequality can lead to the increase of political stability (Nagle, 1974), which depends on the character of political institutions that exist in a country (Muller, 1988). Woo (2011) introduced volatility of fiscal politics as a new channel for explaining negative relations between inequality and growth.

It is also important to examine whether the sources of economic growth differ depending on a level of development, and if the mechanism by which economic inequality affects economic growth changes as well. In accordance with the said the third, the so called "unified approach" was developed, that tries to reconcile the differences between the previous two approaches 
(Galor, 2000). With unified approach there are two phases of economic growth. With lower level of development, the accumulation of physical capital represents basic source of growth and then Kaldor's mechanism according to which the increase of economic inequality leads to the increase of average savings rate, increase of investment rate and consequently to the increase of growth rate as well. However, upon reaching certain level of development, the significance of the source of economic growth changes, so that the priority is given to human capital. Hence, in accordance with this approach, the traditional approach refers to lower levels of development, but not to the situation when a higher level of economic growth is reached (Thorbecke and Charumilind, 2002). According to Galor (1996) on lower level of development, inequality can stimulate the growth since the capital in financial form is a rare resource, and investment requires the existence of savings. Since the savings is formed by richer classes of population, economic inequality can be considered favorable. On the other hand, the availability of financial capital is higher on higher levels of development, which increases the income rate on investments in human capital. In this stage, the poorer classes of population are more jeopardized since they do not have neither the possibility for investment in education nor the access to mortgage that would enable them to provide the missing assets on loan market. In accordance with the said, a bigger inequality in income distribution would lead to falling into a trap of poverty of one part of population, which would negatively reflect economic growth due to the insufficient utilization of resources.

\section{REVIEW OF EMPIRICAL RESEARCHES OF INTERDEPENDENCY OF ECONOMIC INEQUALITY AND ECONOMMIC GROWTH}

Referring to the research of the Organization for Economic Cooperation and Development (OECD), Sherman (2014) emphasizes that economic growth decreases as a result of larger concentration of income and that the gap between the rich and the poor has been on the biggest level in many countries so far. OECD analysis has shown the existence of negative and statistically significant relation between economic growth and economic inequality. Namely, the growth of inequality for GINI points is related to a decrease in economic activity of $0.35 \%$ annually. Okun (1975) emphasized that one cannot have perfect equality and efficiency at the same time. Brueckner and Lederman (2015) started from the assumption that the effects of economic inequality on economic growth differ in rich and poor countries. Empirical results confirmed that the growth of economic inequality contributes to economic growth, and the same conclusion cannot 
42 | ECONOMIC GROWTH AND ECONOMIC INEQUALITY IN VISEGRÁD COUNTRIES: EMPIRICAL ANALYSIS

be made for developing countries. This conclusion is also in accordance with pioneer work of Galor and Zeira (1993) that examined this relation.

Piketty and Saez (2003) emphasized that the countries with large number of the poor and unequal income distribution, cannot realize significant benefits from strong economic growth. On the other hand, the countries that are characterized by equalized distribution of income and corresponding proportion of rich population can make profit by economic improvement. Atkinson (2002) points out the significance of inequality in the distribution for two reasons. The first refers to the impact of economic inequality on economic growth. The second refers to the fact that convergence through more egalitarian economies promotes economic growth. Deininger and Squire (1996) emphasized that in order to achieve higher growth rates, equal distribution in income share is primarily necessary. Benabou (1996), by summing the results of 23 researches, concluded that initial level of inequality is in negative correlation with long-term rate of economic growth, i.e. that decrease of inequality for one standard deviation increases annual growth rate for GDP per capita for $0.5-0.8$ of percentage points. On the other hand, by using the analysis of panel samples, Barro (2000) established negative relationship between economic growth and economic inequality in initial growth stages, which is positive in a more stable developmental stage. On the basis of such findings, the conclusion is that in poor countries economic inequality slows down economic growth, while in rich countries it improves economic growth. Berumen (2016), who based his research on the analysis of twelve European countries, came to similar conclusions. In spite numerous research endeavors, the relation between inequality and growth has not been unambiguously marked so far. The researchers, by using alternative techniques, come to different conclusions. Introducing time dimension into the analysis brings new, even more complex explanations. Hence, a large number of empirical studies produced results which vary to a great extent. Namely, negative relation of variables has been affirmed by Alesina and Rodrik (1994), Ostry, Berg and Tsangarides (2014) Atems and Jones (2015). Contrary to them, Block (1998) is an advocate of the idea that economic inequality has strong positive impact on economic growth. $\mathrm{He}$ states that too high homogeneity, i.e. egalitarian distribution, negatively affected the growth, since the narrow specialization leads to the reduced alternatives on which the growth can be based in the following period. Positive relation of variables has been established by Brueckner and Lederman (2015) and Cavalcanti and Giannitsarou (2016). The studies that imply nonlinear relationship are also present in literature (Barro, 2008). 
Nemanja Lojanica, Tijana Tubić Ćurčić | 43 Also, a small group of authors and their papers that have not confirmed the existence of relation between research variables (Panizza 2002).

\section{DATA AND METHODOLOGY}

In accordance with basic objective of the paper three variables are used: GINI coefficient, economic growth (EG) and unemployment rate (UN). Interest variables are GINI and EG, while UN is control variable. GINI is expressed on the basis of EU-SILC survey, EG as real rate of economic growth in percentages, and UN as unemployment rate. The data is taken from the site Eurostat. Potential impact of economic growth on the movement of economic inequality was examined in Visegrad countries (Czech Republic, Hungary, Poland and Slovakia). Time frame covers the period from 2005 to 2015 . 11 observations in 4 countries are present, so that we have at disposal 44 observations in total in the balanced panel. Descriptive statistics of variables is shown in Table 1.

Table 1

Descriptive statistics results

\begin{tabular}{lccc}
\hline 2005-2015 & Statistic & GINI & Economic growth \\
\hline Czech Republic & Mean & 25.10 & 2.44 \\
& St. dev. & 0.37 & 3.48 \\
& J-B & 2.82 & 0.75 \\
\hline Hungary & Mean & 27.24 & 1.18 \\
& St. dev. & 2.53 & 3.16 \\
& J-B & 2.63 & 4.30 \\
\hline Poland & Mean & 31.79 & 3.86 \\
& St. dev. & 1.50 & 1.72 \\
& J-B & 6.56 & 0.38 \\
\hline Slovakia & Mean & 25.29 & 3.97 \\
& St. dev. & 1.30 & 4.26 \\
& J-B & 0.77 & 0.70 \\
\hline
\end{tabular}

Note. Author's calculation.

Basic economic model that shows dependency of variables can be shown in the following way:

$G I N I_{i, t}=f\left(E G_{i, t}, U N_{i, t}\right)$

Econometric formulation that will serve for the model of fixed and random individual effects can be shown as:

$G I N I_{i, t}=\gamma_{0}+\gamma_{1} E G_{i, t}+\gamma_{2} U N_{i, t}+\varepsilon_{i, t}$

where $\mathrm{i}=1,2, \ldots . \mathrm{N}$ country index, $\mathrm{t}=1,2, \ldots, \mathrm{T}$ is index that refers to time period, $\gamma_{1}$ and $\gamma_{2}$ are long-term coefficients that show the impact of 
44 | ECONOMIC GROWTH AND ECONOMIC INEQUALITY IN VISEGRÁD COUNTRIES: EMPIRICAL ANALYSIS

independent on dependent variable, $\gamma_{0}$ are the effects specific for national economy, while $\varepsilon_{i, t}$ is error term. Having in mind that the observed countries in this case represent observation units, it is very important to also examine cross-sectional dependencies of observation units. In that sense, Pesaran CD test is used. The results are shown in Table 2 . The corresponding probability is bigger than $5 \%$, and can be said that the effect is not statistically significant. Due to this reason, for the testing of panel test of unit root, the tests of first generation will be used. The tests of first generation imply that there is no dependency of observation units in the panel, and one of such tests is Levin, Lin and Chu (2002).
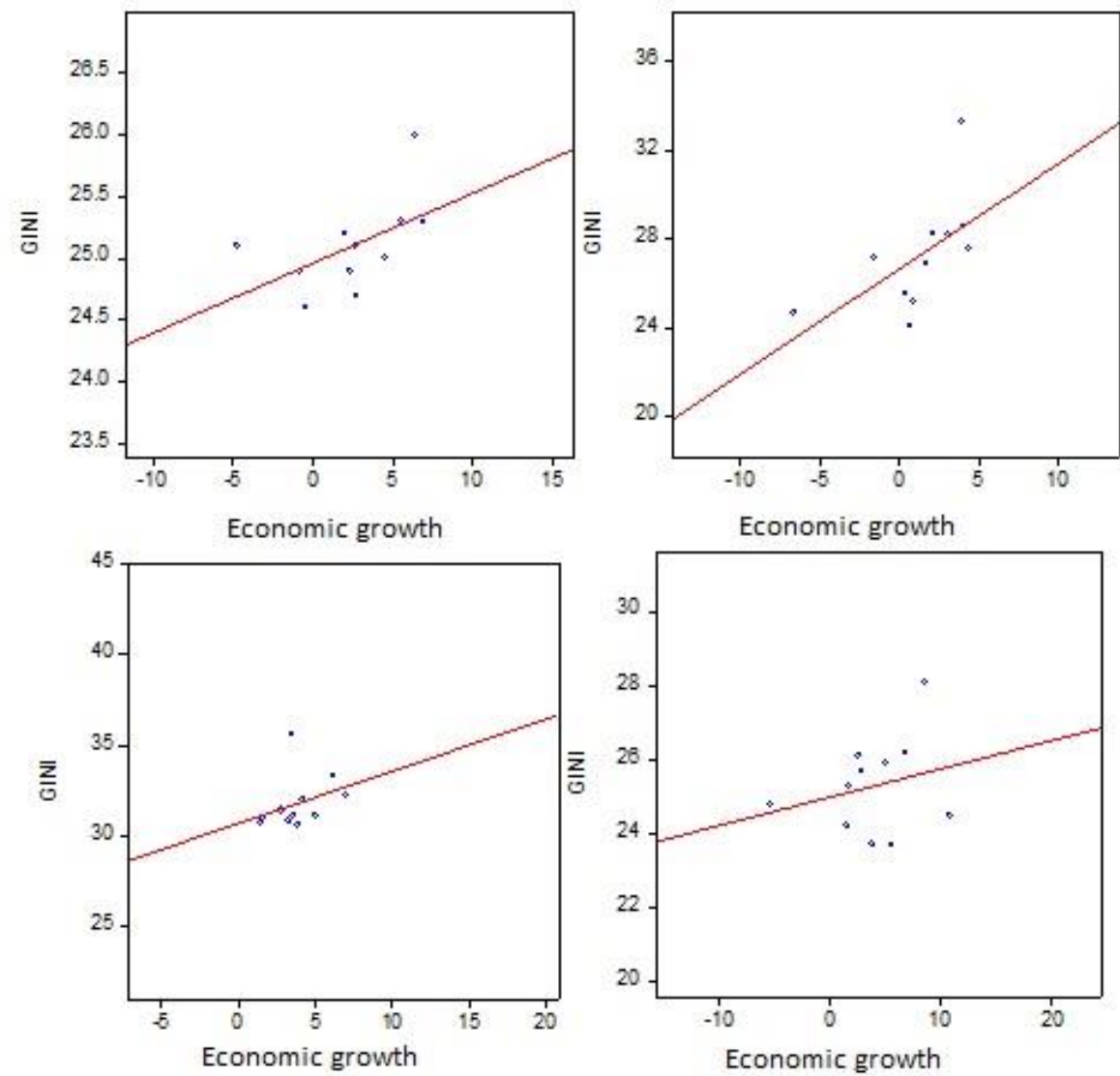

Figure 1. The relationship between economic growth and GINI coefficient (The Czech Republic, Hungary, Poland and Slovakia, respectively) 
Nemanja Lojanica, Tijana Tubić Ćurčić | 45

In the Figure 1 the dependency of economic growth and GINI coefficient is shown. The impact of economic growth on GINI is positive, but the equations were not separately evaluated, since it is necessary to perform formal testing of unit root of panel sample. LLC test is based on individual evaluation of model according to the sample of $\mathrm{T}$ observations for each individual unit.

Table 2

Cross- sectional dependency results

\begin{tabular}{ccc}
\hline $\mathrm{H}_{0}:$ No cross- section & Statistic & Probability \\
dependence in residuals & & 0.92 \\
\hline Pesaran CD & 0.098 & \\
\hline
\end{tabular}

Note. Author's calculation.

By grouping the residuals, the variable of $n^{*} \mathrm{~T}$ dimension is obtained according to which further evaluation is being done. In this way the validity of null hypothesis is tested - that data in the panel are not co-integrated against alternative hypothesis that all individual units form unique equilibrium relationship.

\section{EMPIRICAL RESULT}

By formal testing (Table 3) it was established that all three interest variables are stationed on the level, i.e. that they are of the order of integration I (0). In this way their further testing was enabled with the help of panel regression. In the continuation Hausman test of specification is used for the purpose of establishing whether individual effects are of fixed or stochastic character. Having in mind that the null hypothesis is not rejected, the one with individual effects of stochastic character is established as a valid model (Table 4).

Table 3

Panel unit root test results

\begin{tabular}{cccc}
\hline Variable & \multicolumn{2}{c}{ LLC statistic } \\
\cline { 3 - 4 } & $\boldsymbol{G I N I}_{\boldsymbol{i t}}$ & Constant & Constant and trend \\
$\boldsymbol{E G}_{\boldsymbol{i t}}$ & $-11.68^{*}$ & $-9.11^{*}$ \\
$\boldsymbol{U} \boldsymbol{N}_{\boldsymbol{i t}}$ & $-3.97^{*}$ & $-4.55^{*}$ \\
\hline
\end{tabular}

Note. Author's calculation.

Empirical studies have shown (Roganović and Stankov, 2018), that economic growth can decrease the level of poverty, but in the specific case, evaluated coefficients (Table 5) show that the growth of economic activity does not decrease the inequality in income distribution. On the contrary, a SCHOOL OF BUSINESS, 2/2019, 35-51 
46 | ECONOMIC GROWTH AND ECONOMIC INEQUALITY IN VISEGRÁD COUNTRIES: EMPIRICAL ANALYSIS

$1 \%$ increase of economic growth increases GINI coefficient by $0.19 \%$. Besides, the growth of unemployment (control variable) of $1 \%$ increases GINI coefficients by $0.25 \%$. General specification of model that implies the display of significance of F-test, then the result of Durbin-Watson (DW) test of autocorrelation of first degree, as well as the display of residual from the aspect of testing normality of distribution, is shown in Table 5. Specification of the model is very important since Hausman test cannot be used in the presence of heteroskedasticity and autocorrelation, giving that the bias of variance of regression parameters marks then leads to the bias of the test itself (Jovičić and Dragutinović- Mitrović, 2011).

Table 4

Hausman test results

\begin{tabular}{|c|c|c|}
\hline \multicolumn{3}{|c|}{$\mathrm{H}_{0}$ : cross- section random } \\
\hline$\chi^{2}$ & Degree of freedom & Probability \\
\hline 0.06 & 2 & 0.9678 \\
\hline
\end{tabular}

Note. Author's calculation.

Amri and Nazamuddin (2018) also used panel data in order to examine the connection of economic growth and economic inequality, except that in their case the example of 26 provinces in Indonesia was used and time frame covered the period from 2005 to 2015.

Table 5

Panel regression results

\begin{tabular}{clll}
\hline & \multicolumn{3}{c}{ Dependent variable: $\boldsymbol{G I N}_{\boldsymbol{i t}}$} \\
\hline Variable & coefficient & t-statistics \\
$\mathbf{C}$ & 24.38 & $8.65^{*}$ \\
$\boldsymbol{E G}_{\boldsymbol{i t}}$ & 0.19 & $2.76^{*}$ \\
$\boldsymbol{U N}_{\boldsymbol{i t}}$ & 0.25 & $2.27^{* *}$ \\
$\boldsymbol{R}^{2}$ & 0.23 & \\
F- statistics & $6.10^{*}$ & \\
DW-test & 1.88 & \\
J-B & 3.11 & \\
\hline
\end{tabular}

Note. Author's calculation.

The main study result is that there is a negative and statistically significant connection between economic growth and economic inequality in long-term period, while in short-term period the authors have not found statistically important relation of research variables. By examining the causality of economic growth and economic inequality, Vo Nguyen, Tran and Vo (2018) 
have established on the example of 158 analyzed countries that two-way causality of the observed variables is present. Additionally, the authors have shown that in the countries with the mean level income, economic inequality negatively reflects on economic growth.

\section{CONCLUSION}

Economic reality that is characterized by growing economic inequality, upon longer period of neglecting, has imposed the need that, from the beginning of the 1990s, theoretic and empirical research of the problems of economic inequalities and their implications on the efficiency of functioning of contemporary economies should intensify. After publishing a large number of academic articles and books that have as their aim the estimation of inequality movement and level, the awareness of the significance of the inequality problem has arisen. Piketty (2015) in his work „Capital in the $21^{\text {st }}$ century" showed that developed economies today are on inequality levels that are close to enormous inequalities from the end of the $19^{\text {th }}$ century, as well as that it will soon exceed those levels, unless something significantly changes in the following period. Although the increase of economic inequalities happened gradually and for a long period of time, economic crisis has strong impact on the deepening of inequalities in income distribution, thus slowing down the convergence of life standard and significantly burdening social protection system. Inequality is increased in most of the member countries of European Union and causes the worry in terms of sustainability of growth and social cohesion. According to the data of Eurostat for 2016, in European Union 20\% of the richest population possess, in average 5.2 times higher level of income than $20 \%$ of the poorest population in these countries.

The aim of this research was to examine the impact of economic activities on the movement of inequalities in Visegrad countries. The results of empirical research show that the increase of economic growth of $1 \%$ increases GINI coefficient by $0.19 \%$. The economic growth on the example of analyzed countries does not provide the conditions for a decrease in inequality; moreover, the existing economic growth leads to the growth of inequality in the distribution. Policy-makers in these countries should pay special attention to investment structure (primarily in education), and possible structure of tax policy. In the context of future research, the examination of macro-determinants of economic inequalities would be very important.

\section{REFERENCES}

Alesina, A., \& Perotti, R. (1996). Income distribution, political instability, and investment. European Economic Review, 40(6), 1203-1228. 
48 | ECONOMIC GROWTH AND ECONOMIC INEQUALITY IN VISEGRÁD COUNTRIES: EMPIRICAL ANALYSIS

Alesina, A., \& Rodrik, D. (1994). Distributive Politics and Economic Growth. Quarterly Journal of Economics, 109, 465-490.

Amri, K. N. (2018). Is there causality relationship between economic growth and income inequality?: Panel data evidence from Indonesia, Eurasian Journal of Economics and Finance, 6(2), 8-20

Atems, B., \& Jones, J. (2015). Income inequality and economic growth: a panel var approach. Empirical Economics, 48(4), 1541-1561.

Atkinson, T. (2002). Income Inequality and the Welfare State in a Global Era. School of Policy Studies Queen's University.

Bandelj, N., \& Mahutga, M. C. (2010). How Socio-Economic Changes Shape Income Inequality in Post-Socialist Europe. Social Forces, 88(5), 2133-2161. doi:10.1353/sof.2010.0042

Barro, R. J. (2008). Inequality and growth revisited (No. 11). ADB Working paper series on regional economic integration.

Barro, R. J. (2000). Inequality and Growth in a Panel of Countries. Journal of Economic Growth, 5, 5-32.

Bénabou, R. (1996). Inequality and Growth. NBER Working Paper 5658.

Block, W. (1998). Is Inequality Harmful for growth., SSRN Electronic Journal.

Berumen, A., S. (2016). Did Income Inequality Benefit or Hinder Economic Growth in Europe. The Journal of Social, Political and Economics Studies, 41(2).

Brueckner, M., \& Lederman, D. (2015). Effects of income inequality on aggregate output. The World Bank Group.

Cavalcanti, T. V. V., \& Giannitsarou, C. (2016). Growth and human capital: A network approach. The Economic Journal, 127(603), 1279-1317.

Clarke, G. R. G (1995). More evidence on income distribution and growth. Journal of Development Economics, 47(2), 403-427.

Deininger, K., \& Squire, L. (1996). A New Data Set Measuring Income Inequality. The World Bank Economic Review, 10, 565-591.

Dewhurst, J., \& Mutis-Gaitan, H. (1995). Varying speeds of regional GDP per capita convergence in the European Union, 1981-1991. In Convergence and Divergence Among European Regions (pp. 23-39). London: Pion Limited. 
Nemanja Lojanica, Tijana Tubić Ćurčić | 49

European Union Statistics on Income and Living Conditions (EU-SILC). ttps://ec.europa.eu/eurostat/web/microdata/european-union-statisticson-income-and-living-conditions

European Commission, (2018). Living conditions in Europe. Luxembourg, European Union.

Galor, O., \& Zeira, J. (1993). Income Distribution and Macroeconomics. The Review of Economic Studies, 60(1), 35-52

Helpman, E. (2004). The Mystery of Economic Growth. Belknap Harvard.

Ivanova, M. (2007). Inequality and Government Policies in Central and Eastern Europe. East European Quarterly, 41, 167-204.

Jovičić, M., \& Dtagutinović- Mitrović, R. (2011). Ekonometrijski metodi i modeli. Beograd: Centar za izdavačku delatnost Ekonomskog fakulteta u Beogradu.

Kaldor, N. (1965). Alternative theories of distribution. Review of Economic Studies, 23, 83-100

Keeley, B. (2015). Income Inequality: The Gap between Rich and poor. OECD Insights, OECD Publishing Paris.

Kuznets, S. (1955). Economic growth and income inequality. American Economic Review, 45(1), 1-28.

Levin, A., Lin, C-F., \& Chu, C-S J. (2002). Unit root tests in panel data: Asymptotic and finite- sample properties. Journal of Econometrics, 108(1), 1-24.

Li, H., \& Zou, H. (1998). Income Inequality Is Not Harmful for Growth: Theory and Evidence. Review of Development Economics, 2(3), 318334.

Lundberg, M., \& Squire, L. (2003). The Simultaneous Evolution of Growth and Inequality. Economic Journal, 113(487), 326-344.

Malthus, T. (1798). An Essay on the Principle of Population.

Marx, K. (1867). Capital- A critique of Political Economy.

Milanović, B. (2013). Global Inequality by the Numbers: in History and Now. Global Policy, 4(2), 198-208.

Montiel, P. (2011). Macroeconomics in emerging markets. Cambridge University Press.

Muller, E., N. (1998). Democracy, economic development, and income inequality. American Sociological Review, 53(1), 50-68. 
50 | ECONOMIC GROWTH AND ECONOMIC INEQUALITY IN VISEGRÁD COUNTRIES: EMPIRICAL ANALYSIS

Nagel, J. (1974). Inequality and discontent: A nonlinear hypothesis. World Politics, 26(4), 453-472.

OECD, Arnal, E., \& Forster, M., (2010). Growth, employment and inequality in Brazil, China, India and South Africa: An overview. In Tackling Inequalities Inequalities in Brazil, China, India and South Africa: The Role of Labour Market and Social Policies. Paris: OECD Publishing.

OECD. (2011). Divided We Stand: Why Inequality Keeps Rising. OECD Publishing

Okun, A. (1975). Equality and Efficiency: The Big Tradeoff. Washington D.C.: Brookings Institution Press.

Ostry, J., Berg, A., \& Tsangarides, C. (2014). Redistribution, Inequality and Growth. IMF Staff discussion note.

Panizza, U. (2002). Income inequality and economic growth: Evidence from American data. Journal of Economic Growth, 7, 25-41.

Perugini, C., \& Martino, G. (2008). Income inequality within European regions: Determinats and effects on growth. Review of Income and Wealth, 54(3), 373-406.

Piketty, T. (2015). Kapital u XXI veku, Srpska akdemska misao, prevedeno izdanje, Le capital au XXI ${ }^{\mathrm{e}}$ siècle Editions du Seuil, Paris 2013.

Piketty, T., \& Saez, E. (2003). Income Inequality in the United States 19131998. The Quarterly Journal of Economics, 118(1), 1-39.

Ricardo, D. (1817). On the principles of Political Economy and Taxation. London: John Murray.

Roganović, M., \& Stankov, B. (2018). Uticaj privrednog rasta na smanjenje siromaštva u Republici Srbiji. Škola biznisa, 1, 21-38.

Sherman, E. (2014). Income Inequality hurts Economic Growth, http://www.forbes.com/sites/eriksherman/2014/12/09/incomeinequality-hurts-economic-growth/\#575cb38261d6

Sukiassyan, G. (2007). Inequality and Growth: What Does the Transition Economy Data Say? Journal of Comparative Economics, 35(1), 3556. 
Nemanja Lojanica, Tijana Tubić Ćurčić | 51

Tachibanaki, T. (2005). Confronting income inequality in Japan - a comparative analysis of causes, consequences, and reform. MIT Press.

Thorbecke, E., \& Charumilind, C. (2002). Economic inequality and its socioeconomic impact. World Development, 30(9), 1477-1495.

Vo, D. H., Nguyen, T. C., Tran, N. P., \& Vo, A. T. (2018). What factors affect income inequality and economic growth in middle- income countries?, Journal of Risk and Financial Management, 40, 1-12

Wan, G., Lu, M., \& Chen, Z. (2006). The Inequality-Growth Nexus in the Short and Long Run: Empirical Evidence from China. Journal of Comparative Economics, 34(4), 654-667.

Weil, D.N. (2005). Economic Growth. Addison-Wesley.

Woo, J. (2011). Growth, income distribution and fiscal policy volatility. Journal of Development Economics, 96, 289-313.

Note: This paper is the part of the Project number 179015 and Project number 179062 that is being financed by the Ministry of Education, Science and Technological development of the Republic of Serbia.

Delivered: 04.09.2019. Accepted: 25.11.2019. 